\title{
The Effect of Project-Based Learning Assisted PANGTUS on Creative Thinking Ability in Higher Education
}

\author{
https://doi.org/10.3991/ijet.v15i11.12717 \\ Tri Ana Setyarini ${ }^{\circledR}$, Mustaji, Miftakhul Jannah \\ Surabaya State University, Surabaya, Indonesia \\ trisetyarini@mhs.unesa.ac.id
}

\begin{abstract}
This study aims to determine the effect of Project Based Learning Assisted PANGTUS media on statistics and probability courses on students' creative thinking abilities. The design of this study is true experimental design. All external variables that influence the experiment can be controlled through this design. The design used was a pretest-posttest control group design. The experimental group is the group that gets the application of Project Based Learning Assisted PANGTUS, while the control group is the group that gets guided discovery learning. To find out the differences between the experimental group and the control group, the two groups were given a pretest. Pretest results are said to be good if the value of the experimental group did not differ significantly from the control group. Based on the results of statistical tests show that: (1) the Project Based Learning Assisted PANGTUS model can effectively improve students' creative thinking abilities in higher education; (2) The PjBL assisted PANGTUS model is better than the discovery learning model to be able to improve students' creative thinking abilities in higher education.
\end{abstract}

Keywords - Project-based learning, creative thinking ability, higher education

\section{Introduction}

Ability of creative thinking is a form of product ideas creative thinking of students. Creative thinking is a process that is used when students bring / come up with a new idea. It combines ideas that haven't been done. To succeed in this era of industrial revolution 4.0, students need skills such as creativity [1-5]. Creative thinking can be interpreted as a combination of logical thinking and divergent thinking based on intuition but still in consciousness [6]. Creative character will grow on student self when he trained, accustomed from childhood to pass exploration, inquiry, discovery, and problem solving. Enhancing the ability to think creatively can be done through learning in class. During the learning process in the classroom, lecturers can utilize the material learned to develop or enhance students' creative thinking.

One of the courses at STIKOM Uyelindo Kupang, which requires creative thinking is Statistics and probability. This course equips students to be able to make and use statistics and probabilities of linear regression sub material to develop creative thinking 
content. Learning statistics and probabilities is intended so that students can do data analysis [7], forecasting data that will come do strategies that will be done in the future.

Implementation of statistical learning and probability, have not fully contributed to the students to be directly involved in the formation of knowledge of statistics and probability, though the variety of learning strategies have been implemented [7]. The problem found at this time is students are more dependent on lecturers, whereas students are expected to be independent in learning, able to come up with creative and innovative ideas, and be able to face the challenges and problems they face. The results of the analysis on the syllabus and the statistical and probability lecture event units, which were compiled by the teaching team showed that there was no inclusion of creative thinking skills.

Other findings related to practical implementation is still to be verified, where to test the correctness of the principle or theory with facts, students carry out practical activities as designed or guidelines have been prepared, without given the opportunity to construct students' knowledge and designing practical activities. From the observations made by the quality assurance agency at one of the tertiary institutions, when viewed from the learning process, assessment system, and the results, it is still not in accordance with the target of curriculum achievement. Which means that learning is still not oriented towards active learning that contributes to development of students' creative thinking skills, so there is no evaluation for it. As an alternative solution that can be taken to answer the above problems, namely by implementing Project-Based Learning (PjBL) assisted PANTUSS to improve student's creative thinking abilities in higher education.

\section{Literature Review}

Learning process largely determines the learning outcomes, while the learning process itself is determined by the chosen learning strategy [8]. The ability to think creatively can be developed if creativity is created which allows students to use imagination, develop ideas, produce several possible solutions to various problems, and communicate in various media [9]. Creative thinking is a mental activity related to sensitivity to a problem, considering new information and unusual ideas with an open mind, and can create relationships in solving a problem. The assessment of the characteristics related to creative thinking abilities is described as follows:

- Characteristics of problem understanding skills (fluency): (a) Come up with lots of ideas in problem solving; (b) Give lots of answers in answering a question.

- Characteristics of flexible thinking skills (flexible): (a) Generate variations in the idea of solving a problem or answering a question; (b) Can see a problem from different points of view.

- Characteristics of original skills (originalities): (a) Providing ideas that must be relative in solving problems or answers other than those accustomed to answering a question; (b) Making unusual combinations of parts or elements. 
- Characteristics of detailed skills (elaboration): (a) Developing or enriching other people's ideas; (b) Add, organize or detail or ideas so as to improve the quality of these ideas.

One way to develop or improve students' creative thinking is to apply learning models or strategies that encourage students to think creatively. One such learning model is PjBL. PjBL is a learning strategy that allows infinite students to acquire knowledge and new insights based on students experience through presentations [10]. PjBL emphasizes students to work independently in their learners and accumulate in the form of tangible products. With PjBL, students can get used to solving real problems, to investigate and inquiry. The role of the lecturer in PjBL assisted PANGTUS is to present the problem, design the questions, facilitate the investigation and provide guidance when implementing project tasks. By giving project assignments, it is expected to increase student creativity. Implementation of $\mathrm{PjBL}$ assisted PANGTUS following:

- Determination of the basic question: Learning begins with essential questions, namely questions that can assign students assignments in carrying out an activity.

- Designing a project planning: Planning is done collaboratively between teachers and students. Students are expected to feel "ownership" of the project.

- Arrange schedule: Teachers and students collaboratively arrange activities in completing projects.

- Monitor students and project progress: The instructor is responsible for monitoring student activities while completing the project.

- Assessing the outcome: Assessments are carried out to assist teachers in measuring the attainment of standards, provide feedback on the level of understanding that students have achieved, assist teachers in developing their next learning strategy.

- Evaluate the experience: At the end of the learning process, teachers and students reflect on the activities and results of projects that have been carried out.

\section{Method of Research}

This research has the characteristics, namely: (1) natural background which means it starts from a real problem that is the creativity of students in statistical subjects and probability is still lacking; (2) humans as instruments, where researchers as the main instrument in planning, implementing, observing, collecting data, analyzing data, and draw conclusions, as well as make a report; (3) the method used is qualitative, this is because in the study conducted observations, interviews and documentation; (4) data analysis in this research is inductively meaningful according to the facts and based on the data collected so that it can draw conclusions; (5) descriptive means this study aims to describe ways to improve students' creative thinking through Project Based Learning in Statistics and probability courses, and (6) research is more concerned with process than results. type of research is classroom action research, where research collaborative with cognate faculty to improve and enhance the quality learning undertaken by each cycle. In class action research there are four stages in each cycle, namely Planning, action, observation and reflection [11]. 
The research to improve students' creative thinking through the $\mathrm{PjBL}$ assisted PANGTUS is located at STIKOM Uyelindo Kupang. Data collected in this study are: (1) The results of the validation of learning tools in the validation sheet; (2) The results of observations on students during the PjBL assisted PANGTUS process, namely products in the form of statistical learning media and probabilities for material, reports, and implementation discussion; (3) The test will be used in the form of a written test to evaluate how much the ability of students to think creatively in designing statistical learning media and probability; (4) Results of interviews with the four research subjects; (5) Results of field notes during the learning process. Measuring instruments in testing the validity of the research instrument will use a manual formula that is the product moment correlation with the rough grading [12]. Reliability of instrument test will use analytical reliability with Alpha Cronbach technique.

\section{$4 \quad$ Results and Discussion}

\subsection{Development of project-based learning applications}

Development application of PjBL assisted PANGTUS. This development uses information technology to spread educational information and knowledge as a paradigm of modern education. This application provides supporting tools in developing projectbased learning applications related to design.

\subsection{Implementation}

The interface model of PjBL assisted PANGTUS can be delivered as Figure 1.

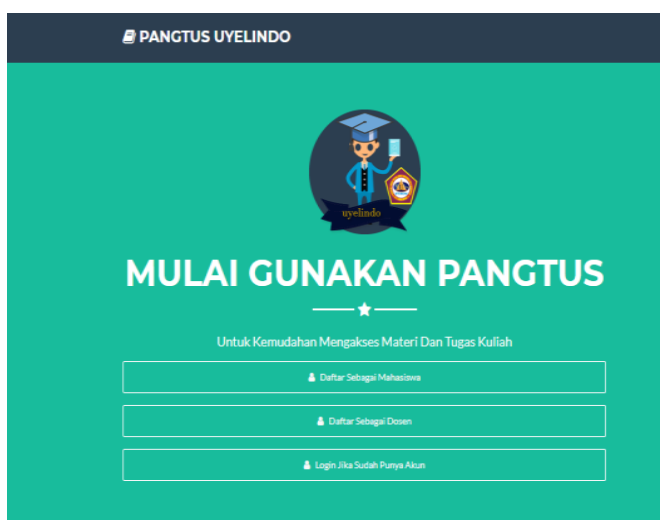

Fig. 1. Main Page of PANGTUS. 

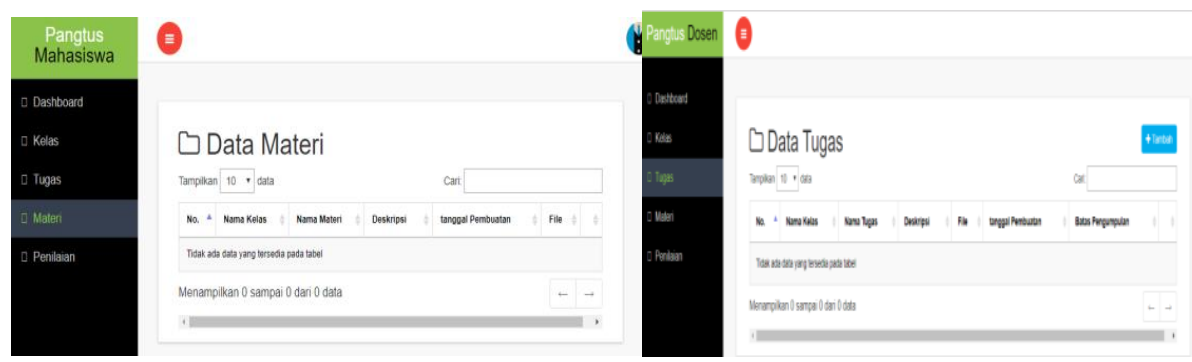

Fig. 2. Data Page of Student and Lecturer

The main page contains to login as a student or as a lecturer. And if you already have an account, you can enter the next step. Student data page is there managing, Class tasking, Material, Assessment. T Visible who are managed by admin. Pages of lecturer of data that can be managed is Class, Tasks, Content, Assessment. Evaluation.

\subsection{Reliability and validity}

The data is entered into the validity and reliability test using IBM SPSS 21 . The results of validity and reliability show that learning tools, learning media, and research instruments are proven to be valid and reliable.

\subsection{Learning outcomes}

After learning is done using the PjBL assisted PANGTUS in the experimental class and the guided discovery learning model in the control class is then given a posttest in both classes. Based on the Independent T-test calculation, the mean (mean) for the pretest of the experimental class 78 and the control class 70 . Then, the results of the calculation using the sign test obtained significance value. Sig (2-tailed) of 0.02 or significance $<0.05(0.02<0.05)$. Thus, it can be concluded that there are differences in the average posttest value of the control class and the average posttest value of the experimental class. It's can be interpreted that there is an influence in increasing students' creative thinking abilities in the implementation of statistical and probability using model of PjBL assisted PANGTUS in STIKOM Uyelindo Kupang. Hay Lock [13] says creative thinking has various levels as students have different levels of intelligence. Because women's creative thinking is an expression of the process of creative thinking, creative thinking also has a level or level. The results of research on the use of ICT in learning can improve student learning outcomes [14-19].

\section{Conclusion}

Based on the results of statistical tests show that the PjBL assisted PANGTUS model can effectively improve students' creative thinking abilities in higher education. The PjBL assisted PANGTUS model is better than the discovery learning model to be able 
to improve students' creative thinking abilities in higher education. The fundamental implication of the results of this study is the PjBL assisted PANGTUS model can be used as an alternative to improve students' creative thinking skills in higher education. Further research can be carried out to test PjBL assisted PANGTUS in other subjects and as a reference in the development of technological education innovations in other countries.

\section{Acknowledgement}

This research was supported by the Uyelewun Indonesia Kupang Foundation and the STIKOM Uyelindo Kupang.

\section{$7 \quad$ References}

[1] Astutik, S., \& Prahani, B.K. (2018). The practicality and effectiveness of collaborative creativity learning (CCL) model by using PhET simulation to increase students' scientific creativity. International Journal of Instruction, 11(4), 409-424. https://doi.org/10.12973/iji. 2018.11426a

[2] Raj, H. and Saxena, D.R. (2016). Scientific creativity: A review of researches. European Academic Research, 4, 1122-1138.

[3] Suyidno, Nur, M., Yuanita, L., Prahani, B.K., \& Jatmiko, B. (2018). Effectiveness of creative responsibility-based teaching (CRBT) model on basic physics learning to increase student's scientific creativity and responsibility. Journal of Baltic Science Education, 17(1), 136-151.

[4] Zulkarnaen, Supardi, Z.A.I, \& Jatmiko, B. (2017). Feasibility of creative exploration, creative elaboration, creative modeling, practice scientific creativity, discussion, reflection (C3PDR) teaching model to improve students' scientific creativity of junior high school. Journal of Baltic Science Education, 16(6), 1020-1034.

[5] Blascova, M. (2014). Influencing academic motivation, responsibility and creativity. Procedia - Social and Behavioral Sciences, 159, 415-425. https://doi.org/10.1016/j.sbspro. $\underline{2014.12 .399}$

[6] 1997. The State-of-Art in Mathematical Creativity. Zentralblatt fur Didaktik der <athematik (ZDM)- The International on Mathematics Education.

[7] Akinogu \& Ozkardes Tandagon. 2007. The effects of problem based active learning in Science education student's achievement, attitude and concept learning. Eurasia Journal of Mathematics Science and Technology Education. 3(1) 71-81.

[8] Sagala, S. (2007). Konsep dan makna pembelajaran untuk membantu memecahkan problematika belajar dan mengajar. Bandung; Alfabeta.

[9] Costantino, T. (2011). Researching creative learning: A review essay. International Journal of Education \& the Art. 12(7), 1-6.

[10] Thomas, J.W., Margendoller, J.R., \& Michaelson, A. 2000. Project-Based Learning: A. Handbook for Middle and High School Teachers.

[11] Akbar, Sa'dun. (2010). Penelitian Tindakan Kelas. Yogyakarta: Cipta Media.

[12] Sevilla, C.G., Ochave, J.A., Punsalan, T.G., Regala, B.P., and Uriarte, G.G. (1984). An introduction to research methods. Quezon City: Rex Printing Company. 
[13] Haylock, D. 1997. Recognising mathematical creativity in schoolchildren. ZDM, 29(3), 6874.

[14] Astutik, S., \& Prahani, B.K. (2018). The practicality and effectiveness of collaborative creativity learning (CCL) model by using PhET simulation to increase students' scientific creativity. International Journal of Instruction, 11(4), 409-424. https://doi.org/10.12973/iji. 2018.11426a

[15] Gong, Y. (2018). Innovative English Classroom Teaching Based on Online Computer Technology in Rural Middle and Primary Schools. International Journal of Emerging Technologies in Learning, 13(10), 4-14. https://doi.org/10.3991/ijet.v13i10.9449

[16] Hariadi, B., Sunarto, M.J.D., Sudarmaningtyas, P., \& Jatmiko. (2019). Hybrid Learning by Using Brilian Applications as One of the Learning Alternatives to Improve Learning Outcomes in College. International Journal of Emerging Technologies Learning, 14(10), 34-45. https://doi.org/10.3991/ijet.v14i10.10150

[17] Madeali, H., \& Prahani, B.K. (2018). Development of Multimedia Learning Based Inquiry on Vibration and Wave Material. Journal Physics: Conference Series, 997(1), 012029. https://doi.org/10.1088/1742-6596/997/1/012029

[18] The, M. M., \& Usagawa, T. (2018). Effectiveness of E-learning Experience through Online. International Journal of Emerging Technologies in Learning, 13(12) 157-176.

[19] Zhang, J. (2018). Blended Learning Innovation Model among College. International Journal of Emerging Technologies Learning, 13(10), 158-170.

\section{Authors}

Dr. Tri Ana Setyarini, work in STIKOM Uyelindo Kupang and the Postgraduate Study Program of Surabaya State University, Surabaya, Indonesia.

Prof. Dr. Mustaji \& Dr. Mihtahkul Jannah, work in Postgraduate Study Program, Surabaya State University, Surabaya, Indonesia.

Article submitted 2019-12-13. Resubmitted 2020-02-23. Final acceptance 2020-02-23. Final version published as submitted by the authors. 